\title{
PERANCANGAN MEDIA PEMBELAJARAN ORGAN PENCERNAAN BERBASIS GAME ROLE PLAYING UNTUK KELAS V SD
}

\author{
Novi Hartanto ${ }^{1}$, Fitro Nur Hakim ${ }^{2}$ \\ ${ }^{1}$ Progdi Desain Grafis Universitas Sains dan Teknologi Komputer Semarang, nopek.art@gmail.com . \\ ${ }^{2}$ Progdi Desain Grafis Universitas Sains dan Teknologi Komputer Semarang, masfitro@gmail.com . \\ Jl. Majapahit 605, Semarang, telp/fax : 024-6717201-02
}

\section{ARTICLE INFO}

Article history:

Received 30 October 2020

Received in revised form 02 November 2020

Accepted 10 November 2020

Available online 02 December 2020

\begin{abstract}
The low standard of values for natural science shows that Indonesia is still lagging behind other countries. This can be seen from the data from the results of the PISA survey conducted by the OECD in 2003 which states that the standard for Natural Sciences in Indonesia is 360.16, while the standard for Natural Sciences (IPA) in the world is 484.84. This data shows that the average score of Natural Sciences subjects is still very low. There are many factors that underlie the low value of IPA in Indonesia. one of them is the assumption that this subject is difficult. In addition, students also find this subject boring and uninteresting. Therefore, this study intends to develop alternative media for fifth grade students to help them learn science, namely in the form of an RPG game that can be played via a computer.
\end{abstract}

Keywords: Game Edukasi; Organ Pencernaan; Media Pembelajaran

\section{PENDAHULUAN}

Ilmu Pengetahuan Alam (IPA) merupakan salah satu cabang ilmu yang penting bagi perkembangan peradaban manusia. Dengan Ilmu Pengetahuan Alam (IPA), manusia mampu membangun perkembangan peradaban bagi negaranya. Di Indonesia, perkembangan Ilmu Pengetahuan Alam (IPA) masih jauh tertinggal dari negara-negara lainnya. Hal tersebut dapat dilihat dari survei PISA yang dilakukan oleh OECD tahun 2003 yang menunjukkan bahwa standar mata pelajaran Ilmu Pengetahuan Alam (IPA) di Indonesia adalah 360,16 sedangkan standar mata pelajaran Ilmu Pengetahuan Alam (IPA) di dunia adalah 484,84. Data tersebut membuktikan bahwa skor rata-rata untuk mata pelajaran Ilmu Pengetahuan Alam (IPA) masih sangat kecil.

Banyak faktor yang menyebabkan skor standar mata pelajaran Ilmu Pengetahuan Alam (IPA) di Indonesia sangat kecil, diantaranya karena pelajaran yang dianggap sulit. Pelajaran eksakta terutama Ilmu Pengetahuan Alam (IPA) sering dianggap menakutkan. Terlebih lagi, mata pelajaran ini juga dianggap menjenuhkan dan tidak menarik. Menurut Abdul [1] Ilmu Pengetahuan Alam (IPA) merupakan salah satu cabang ilmu yang dianggap menakutkan bagi kebanyakan siswa. Hal ini juga bisa dibuktikan melalui hasil nilai ujian nasional mata pelajaran Ilmu Pengetahuan Alam (IPA). Sebagai contoh pada Nilai UN IPA tahun 2012 SDIT Assalamah Ungaran, terdapat beberapa nilai siswa yang belum memenuhi standar yang diharapkan sekolah. 
Materi fungsi pencernaan manusia merupakan salah satu materi penting yang diajarkan pada mata pelajaran Ilmu Pengetahuan Alam (IPA) kelas V SDIT Assalamah Ungaran. Materi ini dianggap penting karena merupakan salah satu materi yang muncul pada tes Ujian Nasional. Sayangnya, materi fungsi pencernaan manusia dirasa masih kurang dipahami oleh siswa kelas V. Hal ini dibuktikan dengan hasil evaluasi ulangan harian dimana beberapa siswa belum memenuhi nilai yang diharapkan. Oleh karena itu, dibutuhkan sebuah inovasi dalam pembelajaran, salah satunya dengan media pembelajaran yang interaktif sehingga dapat membantu proses pembelajaran.

Media pembelajaran yang inovatif dapat dibuat dengan memanfaatkan teknologi informasi dan komunikasi. Menurut Sutarman [2] dengan adanya bantuan komputer dan teknologi informasi, maka kualitas pendidikan dapat meningkat dan mempermudah siswa dalam menerima pelajaran. Media pembelajaran yang inovatif dapat berupa multimedia pembelajaran interaktif.

Multimedia pembelajaran berupa game berguna dalam mendukung kegiatan belajar mengajar. Pesona game yang adiktif jika dimanfaatkan dengan berbagai inovasi yang creative akan mampu menjadi pendukung yang baik bagi kegiatan belajar mengajar sekaligus menarik minat motivasi belajar siswa. Namun, sayang belum banyak game yang dibuat untuk fungsi pembelajaran di sekolah dasar khususnya di Indonesia.

Dari uraian tersebut maka terciptalah sebuah ide untuk membangun sebuah media pembelajaran baru dengan memanfaatkan teknologi komputer yaitu membuat suatu aplikasi game edukasi berbasis Role Playing Game (RPG) sebagai media pembelajaran mata pelajaran Ilmu Pengetahuan Alam (IPA) kelas V SDIT Assalamah Ungaran. Dalam penelitian ini dirancang dan dibangun sebuah game edukasi yang dikhususkan pada materi fungsi organ tubuh manusia. Karena semua informasi ditampilkan dengan teks, gambar, suara, dan animasi yang saling terintegrasi serta adanya tuntutan keaktifan pengguna dalam menjalankan aplikasi, game jenis ini akan menjadi alat bantu belajar yang menarik dan mudah dipahami.

Berdasarkan uraian latar belakang yang telah dipaparkan, maka dapat dirumuskan permasalahan yaitu bagaimana merancang dan membangun media pembelajaran berbasis game Role Playing Game (RPG) untuk materi pencernaan manusia yang ada dalam mata pelajaran Ilmu Pengetahuan Alam (IPA) untuk kelas V SDIT Assalamah Ungaran?

Hasil dari penelitian ini bertujuan untuk meningkatkan pemahaman siswa. selain itu, keberadaan game Role Playing Game (RPG) tersebut dapat menjadi media alternatif dapat dimainkan siswa-siswa kelas $\mathrm{V}$ di komputer sehingga dapat mempermudah dan membantu para siswa belajar mata pelajaran IPA khususnya materi fungsi pencernaan.

\section{LANDASAN TEORI}

\subsection{Teori Media Pembelajaran IPA}

Media Pembelajaran secara umum adalah alat bantu proses belajar mengajar. Segala sesuatu yang dapat digunakan untuk merangsang pikiran, perasaan, perhatian dan kemampuan atau ketrampilan pebelajar sehingga dapat mendorong terjadinya proses belajar, sedangkan menurut Briggs [3], Media pembelajaran adalah sarana fisik untuk menyampaikan isi atau materi pembelajaran seperi buku, film, video dan sebagainya.

Proses pembelajaran merupakan proses komunikasi dan berlangsung dalam suatu sistem. Tanpa media, proses pembelajaran sebagai proses komunikasi juga tidak akan bisa berlangsung secara optimal. Media pembelajaran adalah komponen integral dari sistem pembelajaran.

Menurut Sagala [4] pembelajaran mempunyai dua karakteristik yaitu Pertama, melibatkan proses mental siswa secara maksimal, bukan hanya menuntut siswa untuk sekedar mendengar, mencatatkan tetapi menghendaki aktivitas siswa dalam proses berpikir. Kedua, pembelajaran membangun suasana dialogis dan proses tanya jawab terus menerus yang diarahkan untuk memperbaiki dan meningkatkan kemampuan berpikir siswa, yang pada gilirannya kemampuan berpikir itu akan dapat membantu siswa memperoleh pengetahuan yang mereka konstruksi sendiri.

Permendiknas No.22 tahun 2006 tentang Standar Isi memberikan pengertian bahwa Ilmu Pengetahuan Alam (IPA) berkaitan dengan cara mencari tahu tentang alam secara sistematis, sehingga IPA bukan hanya penguasaan kumpulan pengetahuan yang berupa fakta-fakta, konsep-konsep, atau prinsipprinsip saja tetapi juga merupakan suatu proses penemuan. Pendidikan IPA diharapkan dapat menjadi wahana bagi peserta didik untuk mempelajari diri sendiri dan alam sekitar, lebih lanjut dalam diterapkan dalam kehidupan sehari-hari. Prosesnya menekankan pada pemberian pengalaman langsung untuk mengembangkan kompetensi guna menjelajahi dan memahami alam sekitar secara ilmiah. Pendidikan IPA _diarahkan untuk inkuiri guna memperoleh pemahaman yang lebih mendalam tentang alam sekitar. 
Oleh karena itu pembelajaran IPA di sekolah sebaiknya: (1) memberikan pengalaman pada peserta didik sehingga mereka kompeten melakukan pengukuran berbagai besaran fisis, (2) menanamkan pada peserta didik pentingnya pengamatan empiris dalam menguji suatu pernyataan ilmiah (hipotesis). (3) latihan berpikir kuantitatif yang mendukung kegiatan belajar matematika, yaitu sebagai penerapan matematika pada masalah-masalah nyata yang berkaitan dengan peristiwa alam, (4) memperkenalkan dunia teknologi melalui kegiatan kreatif dalam kegiatan perancangan dan pembuatan alat-alat sederhana maupun penjelasan berbagai gejala dan keampuhan IPA dalam menjawab berbagai masalah.

\subsection{Pengertian Pembelajaran Berbasis Game dan Konsep Game Edukasi}

Pembelajaran Berbantuan Komputer (CAI) terkait langsung dengan pemanfaatan komputer dalam kegiatan pembelajaran didalam dan diluar kelas, baik secara individu maupun secara kelompok. CAI dapat diartikan sebagai bentuk pembelajaran yang menempatkan komputer dalam peran guru, dimana siswa berinteraksi secara langsung dengan komputer dan kontrol sepenuhnya ditangan siswa sehingga memungkinkan siswa belajar sesuai kemampuan dan memilih materi pembelajaran sesuai kebutuhannya [5]. Pembelajaran Berbantuan Komputer diambil dari istilah Computer Aided Instruction (CAI). Menurut Idris [6], istilah CAI (Computer Aided Instruction ) menunjuk pada semua software pendidikan yang diakses melalui komputer di mana anak didik dapat berinteraksi dengannya.

Dalam pembelajaran berbasis Komputer tersebut terdapat lima tipe pembelajaran. Arsyad [7] menyatakan, ada lima tipe Pembelajaran Berbantuan Komputer (Computer Aided Instruction) yaitu Driil dan Practice, Tutorial, Simulation, Problem Solving, Educational Games.

Dalam penelitian ini penulis menerapkan penggunaan Educational Games dimana diketahui bahwa games sangat memungkinkan dimanfaatkan sebagai media pembelajaran yang motivatif bagi siswa. Kemampuannya mempengaruhi aspek kognitif dan emosional pengguna secara bersamaan dapat menjadi sebuah kekuatan sebagai media pembelajaran. Game memiliki genre (jenis) yang luas, antara lain : Action, Fighting ( pertarungan ), Aksi-Petualangan, Petualangan, Role Playing Game ( RPG ), Strategi, Puzzle, Simulasi kendaraan, Olahraga, jika dikembangkan berdasarkan kurikulum tertentu dan dikemas dengan tema konten seperti petualangan, pertarungan, strategi dan genre-genre game aksi lainnya akan menjadikannya suatu game edukasi menarik pemainnya. Penerapan desain komputer game akan merubah sistem traditional pedagogic menjadi autonomous pedagogic dalam penerapan ke pendidikan formal dengan konsep dasar pendidikan kurikuler [8]. Jasson [9] menjelaskan bahwa game adalah perpaduan antara sains dan seni dan memiliki potensi media dalam memperkenalkan hubungan, ide, pendidikan, dan kreativitas.

Dalam penelitian ini penulis mengunakan Role Playing Game ( RPG ). Game jenis ini sesuai dengan terjemahannya, merupakan permainan peran yang memiliki penekanan pada tokoh / peran perwakilan pemain di dalam permainan. Para pemain memilih aksi tokoh-tokoh mereka berdasarkan karakteristik tokoh tersebut. Keberhasilan aksi mereka tergantung pada sistem peraturan permainan yang telah ditentukan. Asal tetap mengikuti peraturan yang ditetapkan, para pemain bisa berimprovisasi membentuk arah dan hasil akhir permainan ini [10].

\subsection{Materi yang Diajarkan}

Dalam game yang disusun dalam penelitian ini diajarkan materi-materi fungsi pencernaan antara lain, gigi, proses pencernaan, macam - macam enzim, dan fungsi gigi.

\section{METODE PENELITIAN DAN PENGEMBANGAN GAME}

Objek pada penelitian ini adalah SDIT Assalamah Ungaran yang beralamat di Jl. Gatot Subroto No. 133, Ungaran. Pelaksanaan penelitian dilakukan pada tanggal 08 Maret 2014 sampai dengan 10 April 2014.

Dalam penelitian ini ada tiga metode pengumpulan data yang digunakan diantaranya Interview atau wawancara, observasi kelas dan studi dokumentasi. Interview dan wawancara dilakukan secara langsung dengan pihak guru kelas V SDIT Assalamah Ungaran. Data yang diperoleh dalam perancangan aplikasi pembelajaran IPA.

Berdasarkan data yang dikumpulkan game edukasi kemudian dikembangkan secara bertahap. Tahapan-tahapannya adalah sebagai berikut:

\section{Perancangan Konsep Game}

Berdasarkan hasil studi pustaka dan survey lapangan yang dilakukan, maka didapatkan perancangan konsep game yang didasarkan pada hasil analisis kebutuhan siswa-siswi kelas V SDIT Assalamah yang 
nantinya akan menjadi pengguna game ini. Mengacu pada hasil analysis kebutuhan tersebut didapatkan sebuah konsep game dengan judul "The Story Of Stomach". Secara umum, game ini merupakan tipe game petualangan yang mengajak penggunanya untuk memerankan sebuah tokoh ksatria yang ditugaskan untuk menyelamatkan seorang Permaisuri. Soal - soal evaluasi tentang pelajaran disisipkan pada game, konsepnya bertemakan pembelajaran organ pencernaan. Penambahan itemnya juga bersifat edukasi misalnya item Pedang yang merepresentasikan unsur membunuh racun dalam pencernaan, item Healing Potion yang merepresentasikan unsur penawar racun di dalam pencernaan. Ksatria akan menghadapi musuh-musuh untuk membawa kembali Permaisuri yang disandera tersebut.

untuk memudahkan proses pengembangan multimedia game, maka pada tahap desain dibuat diagram alir (flowchart), storyboard dan rancangan antarmuka pemakai, masing-masing bagian diuraikan sebagai berikut:

a. Diagram Alir ( Flowchart)

Flowchart menggambarkan urutan-urutan tampilan antarmuka pemakai pada multimedia tersebut. Flowchart menu utama dalam game pembelajaran ini ditunjukkan pada Gambar 3.1

Menu utama pada Gambar 3.1 terdapat pilihan untuk memulai permainan baru atau melanjutkan permainan. Apabila memilih permainan baru, maka akan terdapat tahap selanjutnya untuk membuat karakter jika memilih menu melanjutkan permainan, maka pengguna tidak perlu membuat karakter baru lagi dan langsung berada pada saat melakukan save data saat permainan.

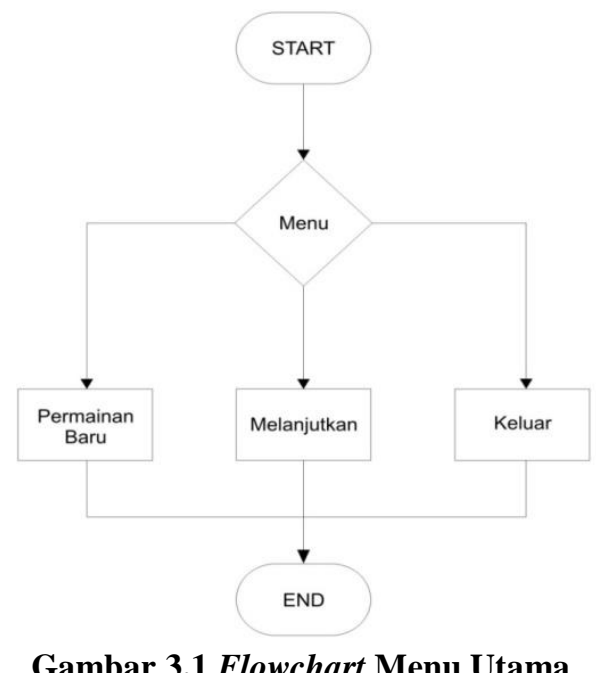

Pada pembelajaran interaktif ini, karakter dapat bergerak ke semua arah, ke atas, bawah, kanan dan kiri yang akan memudahkan pengguna untuk bergerak dan memilih kelas yang diinginkan. Flowchart berjalan ditunjukkan pada Gambar 3.2. 


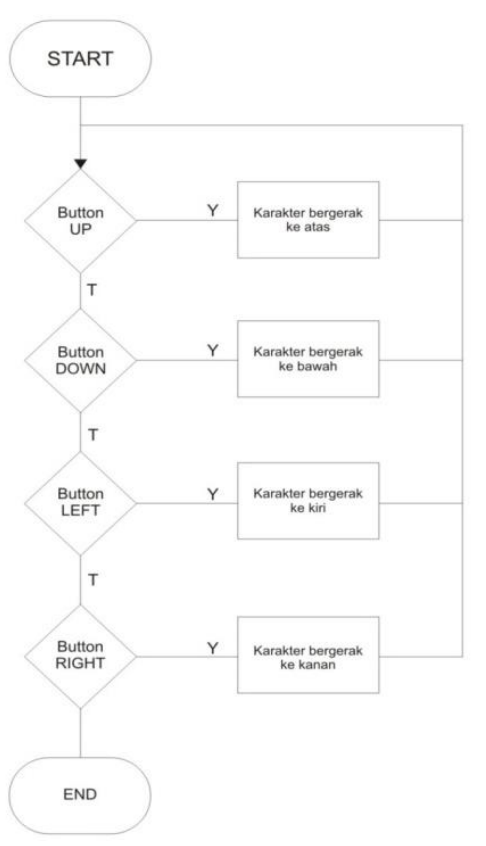

\section{Gambar 3.2 Flowchart Berjalan}

Button disini digunakan sebagai tambahan untuk karakter agar karakter terkesan lebih hidup dan lebih menarik dimainkan, mulai dari mengeluarkan skill pedang dan tameng.

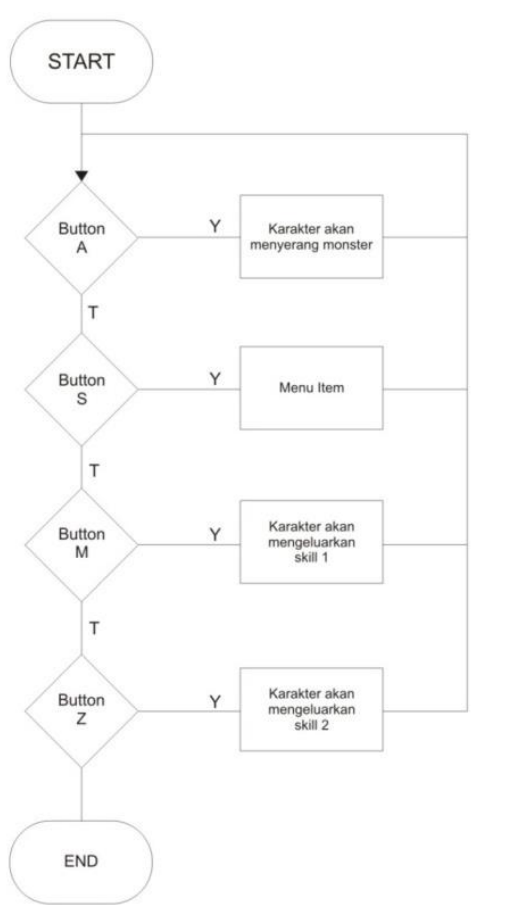

\section{Gambar 3.3 Flowchart Button Tambahan}

b. Sinopsis

Game pembelajaran ini menuntut siswa aktif dalam menjalankan sebuah misi dengan membunuh semua monster-monster, monster tersebut berupa gelembung putih, anjing, landak dan yang terakhir monster Garuda.

Monsternya juga bersifat edukasi misalnya Monster Gelembung Putih merepresentasikan unsur Enzim Pepsin di dalam tubuh, Monster Anjing merepresentasikan unsur Enzim Renin di dalam tubuh, 
Monster Landak merepresentasikan unsur Enzim Lipase Gastrik di dalam tubuh, kemudian Monster Garuda merepresentasikan unsur Enzim Ptialin di dalam mulut.

Dalam game ini, Karakter Pangeran berjalan untuk menuju Istana Kerajaan, setelah memasuki Istana, Pangeran diberi surat tugas untuk menyelamatkan seorang putri yang diculik oleh monster Garuda. Untuk sampai ke tempat monster tersebut, Pangeran harus melawan anak buah dari monster Garuda, serta Pangeran harus menjawab beberapa pertanyaan yang bersifat edukasi (mengenai hal-hal Organ Pencernaan) yang diberikan oleh penjaga pintu kerajaan dan penjaga gerbang di sekitar hutan. Agar bisa sampai pada kediaman monster tersebut, Pangeran harus mengalahkan semua anak buah dari monster Garuda, kemudian menyelamatkan seorang putri dan membawanya ke istana untuk dikembalikan kepada Raja. Sinopsis ini merepresentasikan sebuah perjalanan atau explorasi visual kedalam Organ Pencernaan, yaitu organ pertama Hati. Didalamnya game diwujudkan dalam pertanyaan-pertanyaan yang harus dijawab "Pangeran". Usus didalam game divisualisasi menjadi jalan tokoh "Pangeran". Organ Hati didalam game divisualisasi menjadi Istana Monster. Perut didalam game divisualisasi menjadi Map di dalam hutan. Organ kerongkongan didalam game divisualisasi menjadi Jalan menuju Istana Monster.

c. Perancangan Antarmuka Pemakai

Antarmuka pemakai pada multimedia game dibuat layout atau latar buku sehingga dapat menarik perhatian pengguna, yakni siswa.

\section{The Story of Stomach}

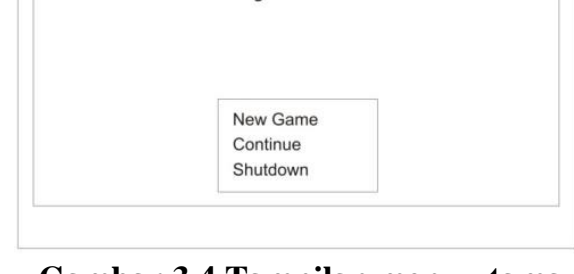

Gambar 3.4 Tampilan menu utama

Tampilan mепи utama dalam game pembelajaran ini ditunjukkan pada Gambar 3.4. Pada menu utama ini terdapat tiga pilihan, yaitu permainan baru, melanjutkan permainan dan keluar. Apabila memilih melanjutkan permainan, maka kita akan masuk pada menu untuk memilih data yang telah kita simpan sebelumnya..

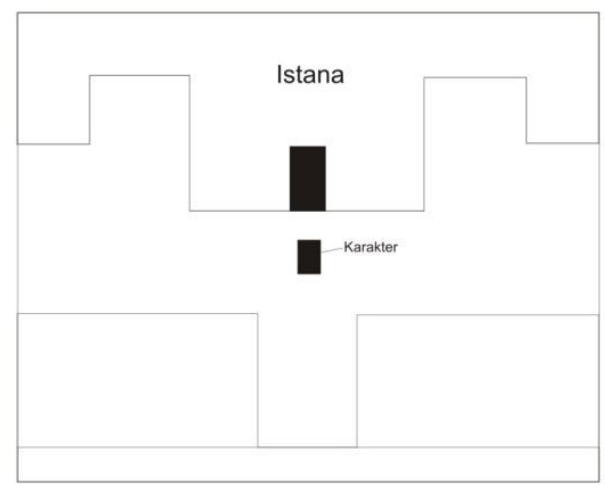

Gambar 3.5 Tampilan Di luar istana 


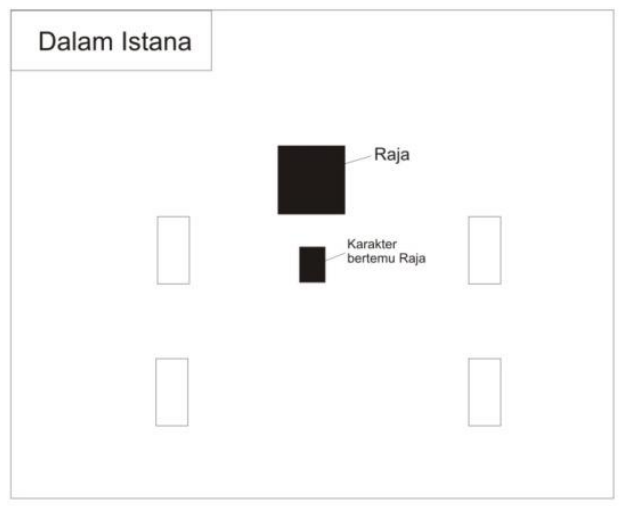

\section{Gambar 3.6 Tampilan Di dalam istana}

Setelah Pengguna atau User masuk game akan ditampilkan di luar istana, Game ini baru akan dimulai. Tampilan di luar istana dalam game ini ditunjukkan pada Gambar 3.5.

Karakter akan diarahkan memasuki istana untuk menemui Sang Raja. Kemudian karakter akan diberi petuah atau perintah untuk menyelamatkan seorang putrid dan karakter akan diberi beberapa uang dari Sang Raja. Tampilan di dalam istana dalam game pembelajaran ini ditunjukkan pada Gambar 3.6.

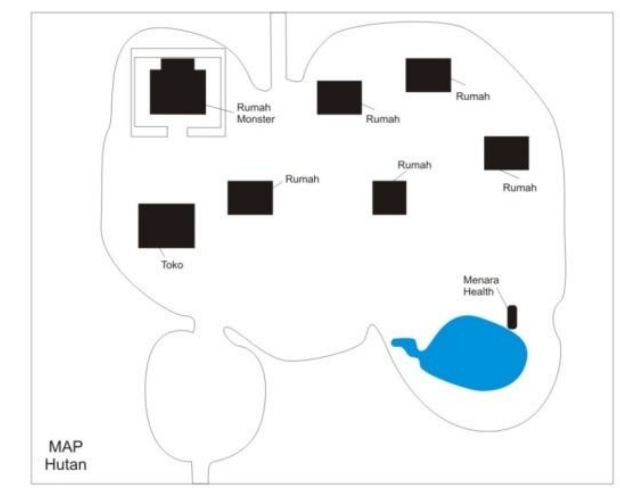

Gambar 3.7 Tampilan Map Hutan

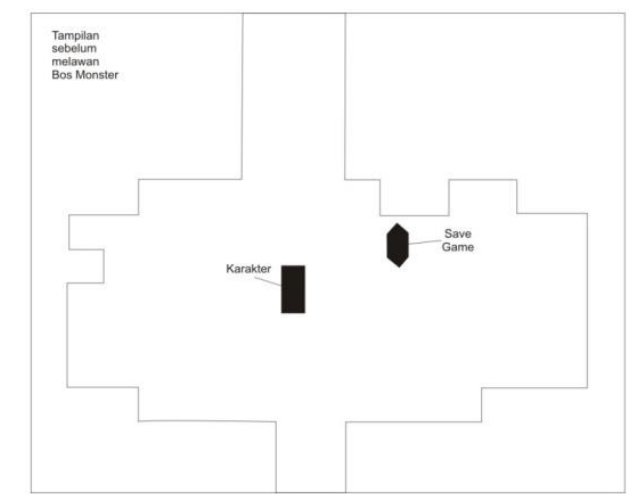

Gambar 3.8 Tampilan Halaman Istana Monster

Setelah berhasil melewati beberapa tahap. Karakter akan memasuki wilayah Utama Istana monster. Di dalamnya, karakter akan melawan monster kecil yang bersifat energik. Map ini merepresentasikan Pangeran menyimpan energi. Di map ini karakter juga diberi kesempatan untuk menyimpan game yang sudah dimainkan sampai tahap ini. Tampilan halaman istana monster ditunjukkan pada Gambar 3.8.

2. Tahap Implementasi 
Objek-objek berupa tombol-tombol atau Movie Clip yang telah dibuat sebelumnya pada antarmuka belum dapat melakukan fungsi apapun. Oleh karena itu, pada tahap ini diberikan code kepada objek-objek tersebut supaya objek-objek tersebut berfungsi seperti yang diinginkan. Code dalam RPG Maker XP dinamakan ActionScript dan dalam pengembangan multimedia ini digunakan ActionScript 2.0. Pemberian ActionScript pada antarmuka yang telah dibuat sebelumnya, memungkinkan membuat sebuah multimedia yang interaktif dan dinamis.

Terdapat 4 komponen utama yang membentuk engine game. Komponen-komponen tersebut ialah:

a. Database, yang meliputi Karakter, Senjata, Map, Gambar dan Music. Karakter game ini meliputi Pangeran Awel, Putri Nanazh, dan Raja Bul bul dan Class karakter, yang terdiri dari Pangeran dan Putri. Senjata yang disediakan adalah Pedang dan Kait. Map-nya meliputi Depan Kastil, Hutan, Gerbang, dan Kediaman Monster. Gambar dimana merupakan Title Screen = Berlatar Buku. Dan yang terakhir, Music, dimana terdapat Backsound yang merupakan musik instrumental dan Sound Efek yang berupa suara pedang, tangkis, tertusuk, menusuk

b. Game Object, meliputi sprite dan latar belakang.

c. Artificial Intelligence, meliputi Monster ( Path Finding) dan Penjaga

b. Game Control

- Keyboard

1) Tombol arah atas, karakter berjalan ke arah atas.

2) Tombol arah kanan, karakter berjalan ke arah kanan.

3) Tombol arah bawah, karakter berjalan ke arah bawah.

4) Tombol arah kiri, karakter berjalan ke arah kiri.

5) Tombol huruf A, karakter akan menyerang.

6) Tombol huruf S, menampilkan menu item

7) Tombol huruf M, karakter akan mengeluarkan skill 1.

8) Tombol huruf Z, karakter akan mengeluarkan skill 2.

3. Tahap Penanaman Visual dan Audio pada Game

Tahap ini menanamkan aspek visual berupa gambar peta, karakter, dan latar belakang Aspek audio juga ditambahkan berupa music background, dan sound effect.

I - Intro, berupa gambar kastil untuk memulai ekplorasi kedalam game (organ pencernaan).

II - Permainan, berupa petualangan melawan monster, monster tersebut adalah racun racun makanan di dalam tubuh kita yang harus dihancurkan. Monster tersebut dapat dihancurkan dengan pedang dan skill yang dimiliki oleh Sang Pangeran. Suara menggunakan Effect pedang dan Effect ledakan.

III - Ending, berupa penyelamatan putri dan membawa pulang putri ke Kastil.

\section{Tahap Pengujian}

Pada tahap pengujian akan mengunakan metode pengujian yang disebut black box (kotak hitam).

Pengujian Black box Digunakan untuk menguji fungsi-fungsi khusus dari perangkat lunak yang dirancang. Dari keluaran yang dihasilkan, kemampuan program dalam memenuhi kebutuhan pemakai dapat diukur sekaligus dapat diiketahui kesalahan - kesalahannya. Pengujian black box berfokus pada persyaratan fungsional perangkat lunak. Dari pengujian black box ini fungsi-fungsi yang tidak benar atau hilang dapat diketahui, seperti kesalahan interface, kesalahan dalam struktur data atau akses database eksternal, kesalahan kinerja dan yang terakhir inisialisasi dan kesalahan terminasi.

\section{Pemaketan (Packaging)}

Tahapan ini merupakan tahap pemaketan multimedia yang telah selesai dibuat. Proses pemaketan berlanjut dengan proses penulisan installer file tersebut ke dalam CD.

\section{HASIL DAN PEMBAHASAN}

\subsection{Kebutuhan Sistem Pendukung}

Untuk mendukung game yang akan dibangun selain membutuhkan perangkat keras juga membutuhkan perangkat lunak, Adapun perangkat lunak dan perangkat keras yang dibutuhkan oleh pemain meliputi OS Windows 98 / 98SE / Me / 2000 / XP, Prosesor Intel Core 2 Duo 2,2 GHz, Memori RAM 1 Gb, Hardisk 80 Gb, VGA 128 Mb, dan Mouse, Keyboard dan Monitor.

Berdasarkan spesifikasi tersebut maka Game dapat dijalankan dengan menggunakan fitur-fitur seperti smooth mode, dengan mengaktifkannya pada Option Game (tekan F1 lalu klik pada fitur yang dinginkan).

JURNAL ILMIAH KOMPUTER GRAFIS Vol. 13, No. 2, Desember 2020




\subsection{Implementasi Rancangan Sistem}

Implementasi dan pembahasan merupakan tahapan yang bertujuan mengubah hasil dari rancangan sistem menjadi bentuk nyata, dalam hal ini berupa aplikasi game yang berjalan pada piranti desktop computer.

1. Tampilan Awal

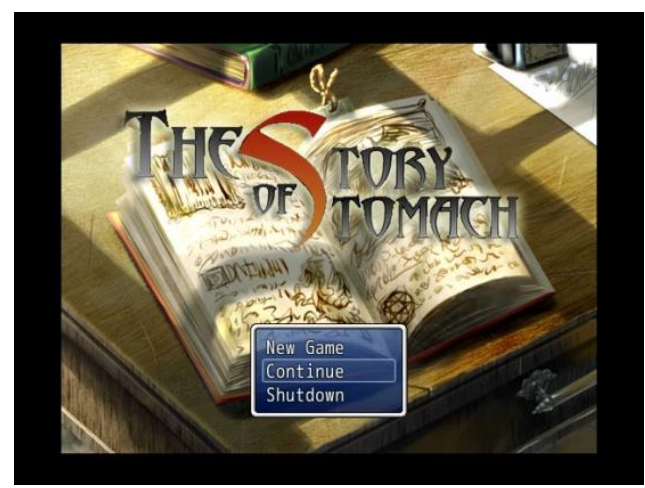

Gambar 4.1 Menu utama

Tampilan awal aplikasi multimedia pembelajaran materi organ pencernaan berbasis game edukasi, disini terdapat pilihan menu untuk pemain. Di dalam tampilan ada tiga menu yaitu, permainan baru, melanjutkan permainan dan keluar permainan. Tampilan Menu Utama ditunjukkan pada Gambar 4.1.

2. Tampilan Intro

Tampilan untuk membuka intro sebelum memulai permainan. Seperti pada Gambar 4.2.

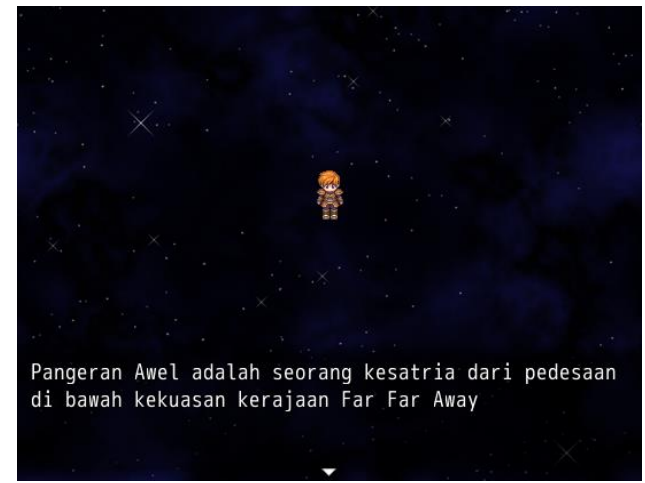

Gambar 4.2 Tampilan Intro

3. Tampilan Awal memulai Game

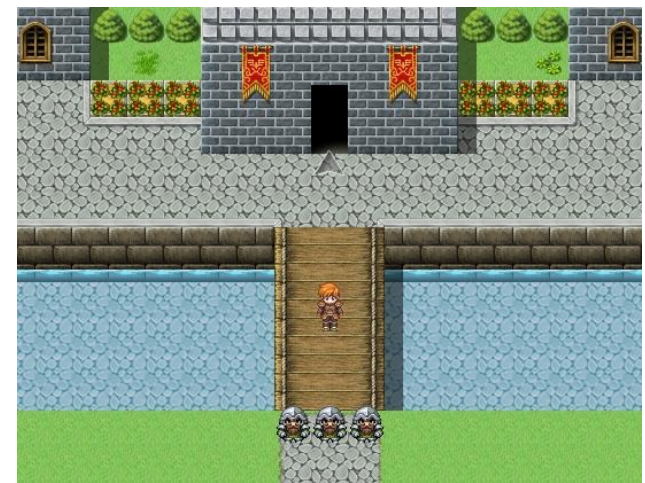

Gambar 4.3 Tampilan diluar Kastil 
Tampilan awal memulai game, karakter berada diluar kastil, kemudian karakter akan diarahkan masuk ke dalam kastil untuk menemui Raja. Tampilan luar Kastil ditunjukkan Gambar 4.3.

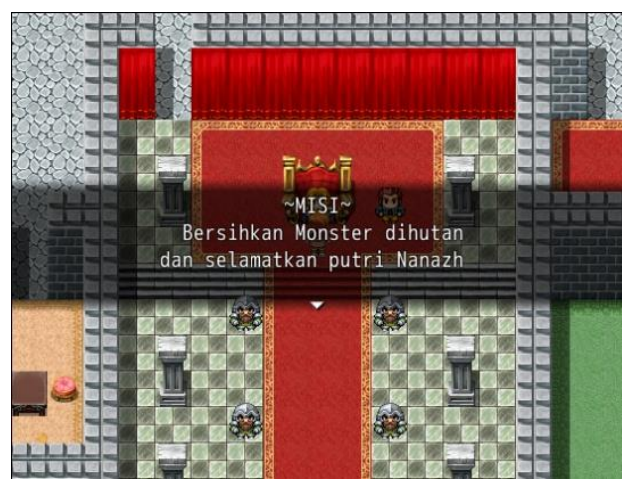

Gambar 4.4. Tampilan di dalam Kastil

Tampilan di dalam kastil pada Game ditunjukkan pada Gambar 4.4. Raja memberikan perintah kepada karakter untuk memberikan menyelamatkan Putrinya dan membasmi para monster di kerajaan Cerna. Kemudian Raja akan memberikan pilihan kepada karakter, pilihan tersebut antara Iya atau Tidak. Tampilan Pilihan pada Game ditunjukkan pada Gambar 4.4.

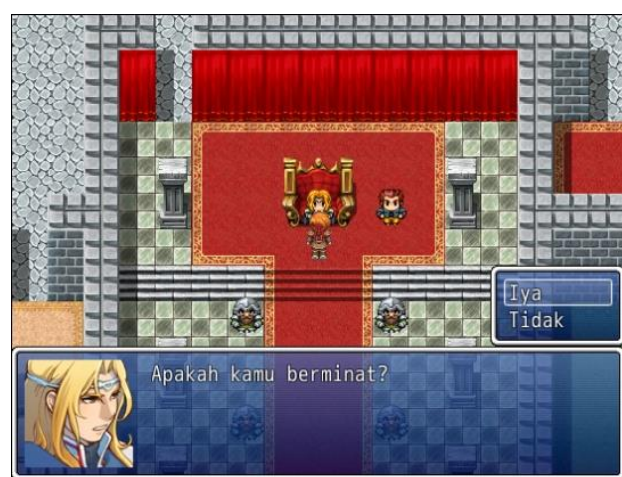

Gambar 4.5 Tampilan Pilihan Raja

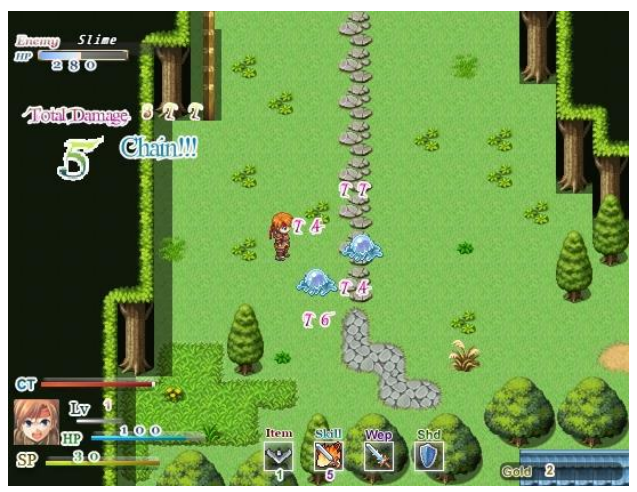

Gambar 4.6 Tampilan Melawan Monster Hutan

Ketika berada di hutan, karakter akan berhadapan dengan monster hutan, karakter ditugaskan untuk membersihkan monster - monster hutan. Tampilan melawan Monster pada Game ditunjukkan pada Gambar 4.6.

4. Tampilan Pertanyaan 


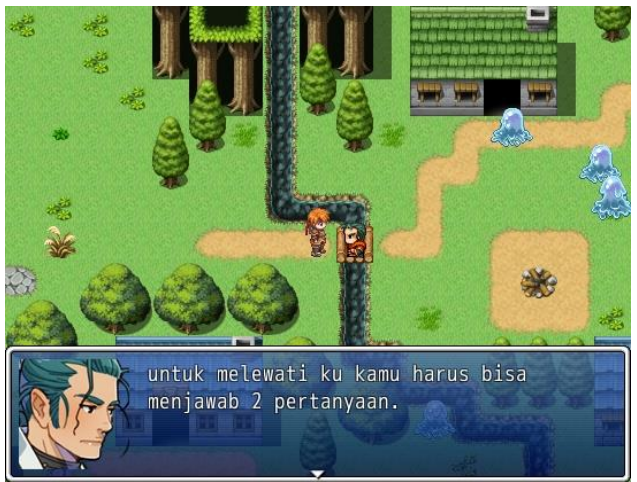

Gambar 4.7 Tampilan dialog dengan penjaga hutan

Ketika di hutan karakter akan bertemu dengan penjaga hutan, kemudian karakter harus menjawab pertanyaan dari penjaga hutan untuk bisa melanjutkan perjalanan. Tampilan dialog ditunjukkan pada Gambar 4.7.

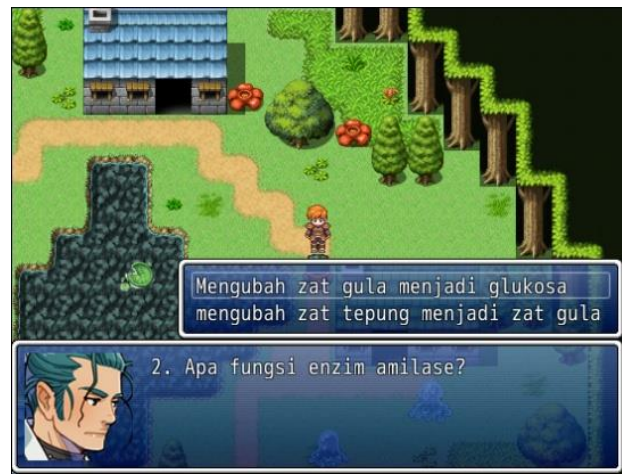

Gambar 4.8 Tampilan petunjuk memilih jawaban

Karakter diberi pilihan jawaban untuk menjawab pertanyaan dari penjaga hutan. Tampilan pilihan jawaban ditunjukkan pada Gambar 4.8.

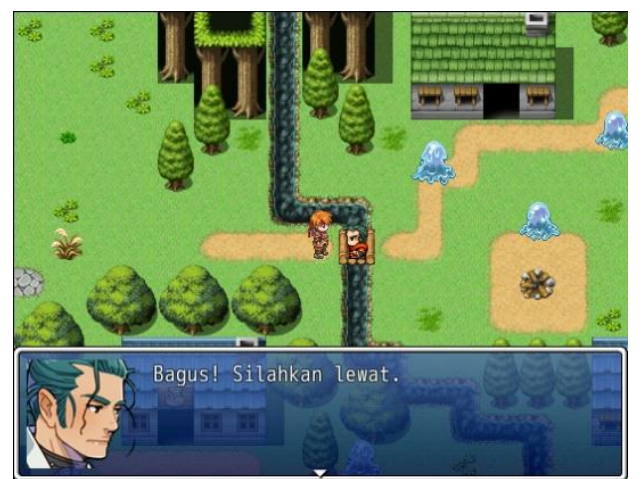

Gambar 4.9 Tampilan apabila jawaban benar 


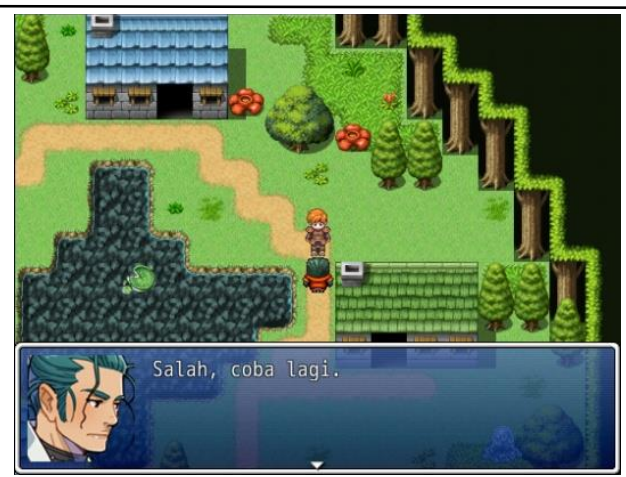

Gambar 4.10 Tampilan apabila jawaban salah

Masing-masing penjaga memiliki dua soal yang harus dijawab. Jika salah dalam menjawab, soal akan diulang hingga jawaban benar. Setelah semua terjawab dengan benar, perjalanan menuju Istana Monster Garuda dapat dilanjutkan.

Jika karakter menggunakan Kristal tersebut, maka akan tampil menu seperti dibawah ini dan pilih tempat penyimpanan untuk menyimpan permainan dan mengisi nyawa kembali seperti semula. Untuk membatalkan penyiman permainan tekan tombol ESC, maka penyimpanan akan dibatalkan. Tampilan info pada Game ditunjukkan pada Gambar 4.11.

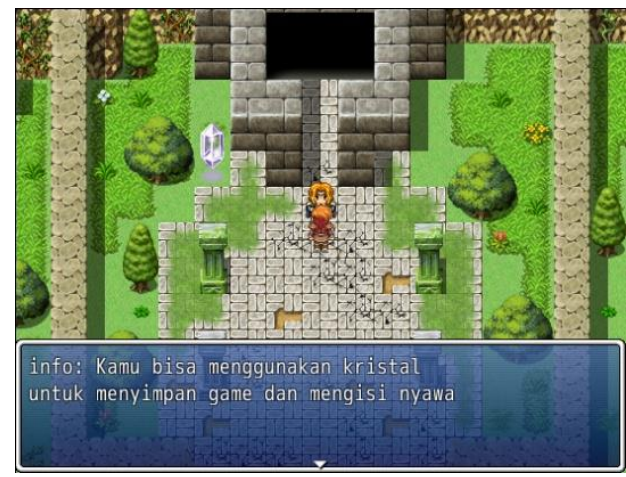

Gambar 4.11 Tampilan Info

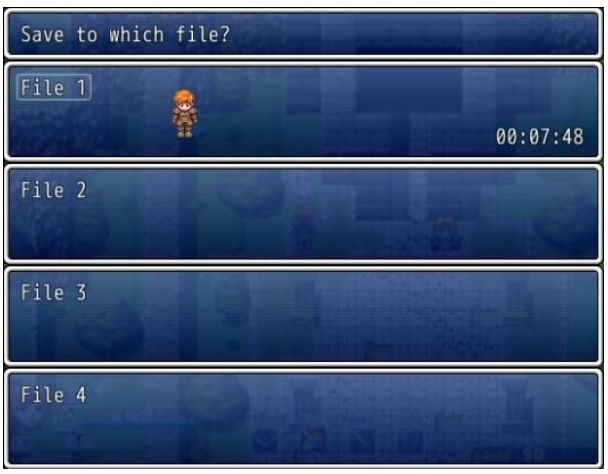

Gambar 4.12 Tampilan Tempat Penyimpanan Game

Setelah berhasil melawan Monster utama, yaitu monster Garuda, Pangeran diperintah membawa Putri kembali ke Istana Kerajaan Cerna, dan mengatarkannya ke Raja Cerna. Gambar 4.13 menunjukan tampilan melawan Monster Garuda. 


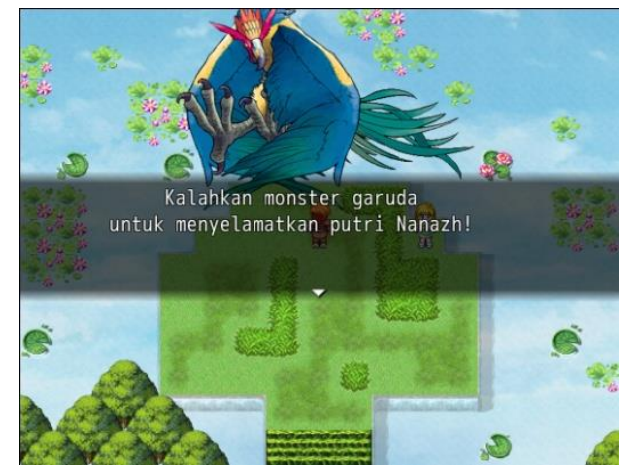

Gambar 4.13 Tampilan melawan Monster Garuda

\subsection{Implementasi Instalasi Program}

Berikut ini adalah tahapan untuk melakukan instalasi program aplikasi multimedia pembelajaran materi organ pencernaan berbasis game :

1. Tahap Pertama Double Klik Icon Setup Game Organ Pencernaan

2. Gambar 4.14 Tampilan Icon Setup PC Game Edukasi Materi organ pencernaan

3. Sesudah di klik kemudian akan tampil jendela Please Select a Language. Sesudah memilih bahasa, tekan tombol Ok untuk melanjutkan proses Instalasi.

4. Kemudian akan tampil jendela Wellcome to the Game Organ Pencernaan Setup Wizard. Tekan tombol Next untuk melanjutkan proses installasi

5. Selanjutnya pilih browse untuk memilih lokasi penyimpanan. Tekan tombol Next untuk melanjutkan proses installasi.

6. Selanjutnya akan tampil jendela Select Shortcuts, pilih Create a Deskstop Icon dan Create Shortcuts in Start Menu. Tekan tombol Next untuk melanjutkan proses installasi

7. Selanjutnya akan tampil jendela Ready to Install. Tekan tombol Install untuk memulai penginstallan.

8. Kemudian akan muncul jendela Installing. Tunggu beberapa saat hingga muncul jendela Completing Game Organ Pencernaan Setup Wizard seperti pada gambar 4.20.

9. Jendela Completing Setup Wizard. Tekan tombol Finish untuk menyelesaikan proses installasi.

\subsection{Pengujian}

Pengujian perangkat lunak ini menggunakan metode pengujian Black Box. Pengujian Black Box Digunakan untuk menguji fungsi-fungsi khusus dari perangkat lunak yang dirancang. Adapun rancangan pengujian sistem yang akan diuji telah dikelompokan dalam tabel di bawah.

\begin{tabular}{|c|c|c|c|}
\hline $\mathrm{NO}$ & $\begin{array}{l}\text { Komponen } \\
\text { Yang Di } \\
\text { Uji }\end{array}$ & Butir Uji & $\begin{array}{l}\text { Jenis } \\
\text { Pengujian }\end{array}$ \\
\hline \multirow[t]{3}{*}{1} & \multirow[t]{3}{*}{ Karakter } & Pangeran & Black Box \\
\hline & & Putri & Black Box \\
\hline & & Raja & Black Box \\
\hline \multirow[t]{5}{*}{2} & \multirow[t]{5}{*}{ Pertanyaan } & Pertanyaan ke -1 & Black Box \\
\hline & & Pertanyaan ke -2 & Black Box \\
\hline & & Pertanyaan ke -3 & Black Box \\
\hline & & Pertanyaan ke -4 & Black Box \\
\hline & & Pertanyaan ke - 5 & Black Box \\
\hline \multirow[t]{2}{*}{3} & \multirow[t]{2}{*}{ Jawaban } & Jawaban Benar & Black Box \\
\hline & & Jawaban Salah & Black Box \\
\hline 4 & Map & Melewati Map & Black Box \\
\hline \multirow[t]{2}{*}{5} & \multirow[t]{2}{*}{$\begin{array}{l}\text { Karakter } \\
\text { Bergerak }\end{array}$} & $\begin{array}{l}\text { Bergerak Ke } \\
\text { Atas }\end{array}$ & Black Box \\
\hline & & Bergerak Ke & Black Box \\
\hline
\end{tabular}




\begin{tabular}{|l|l|l|}
\hline & Bawah & \\
\cline { 3 - 3 } & Bergerak Ke Kiri & Black Box \\
\hline & $\begin{array}{l}\text { Bergerak Ke } \\
\text { Kanan }\end{array}$ & Black Box \\
\hline
\end{tabular}

Berikut ini adalah kasus untuk menguji perangkat lunak yang sudah dibangun menggunakan metode BlackBox berdasarkan tabel diatas rencana pengujian yang telah dibuat sebelumnya.

\begin{tabular}{|c|c|c|c|c|c|}
\hline $\begin{array}{l}\mathrm{N} \\
\mathrm{O}\end{array}$ & $\begin{array}{l}\text { Kasus } \\
/ \\
\text { Diuji }\end{array}$ & $\begin{array}{l}\text { Skena } \\
\text { rio } \\
\text { Uji }\end{array}$ & $\begin{array}{l}\text { Hasil yang } \\
\text { diharapkan }\end{array}$ & $\begin{array}{l}\text { Hasil } \\
\text { Pengujian }\end{array}$ & \\
\hline \multirow[t]{3}{*}{1} & \multirow[t]{3}{*}{$\begin{array}{l}\text { Karak } \\
\text { ter }\end{array}$} & $\begin{array}{l}\text { Karak } \\
\text { ter } \\
\text { Pange } \\
\text { ran }\end{array}$ & $\begin{array}{l}\text { Ketika melawan } \\
\text { monster, } \\
\text { karakter bisa } \\
\text { berkelahi, } \\
\text { mengeluarkan } \\
\text { skill }\end{array}$ & $\begin{array}{l}\text { Berhasil } \\
{[\sqrt{ }]} \\
\text { Tidak } \\
\text { Berhasil } \\
{[\text { ] }} \\
\end{array}$ & \\
\hline & & $\begin{array}{l}\text { Karak } \\
\text { ter } \\
\text { Raja }\end{array}$ & $\begin{array}{l}\text { Ketika Pangeran } \\
\text { menemui Raja, } \\
\text { Raja memberi } \\
\text { Perintah kepada } \\
\text { Pangeran }\end{array}$ & $\begin{array}{l}\text { Berhasil } \\
{[\downarrow \sqrt{ }]} \\
\text { Tidak } \\
\text { Berhasil } \\
{[\text { ] }} \\
\end{array}$ & \\
\hline & & $\begin{array}{l}\text { Karak } \\
\text { ter } \\
\text { Putri }\end{array}$ & $\begin{array}{l}\text { Ketika berhasil } \\
\text { diselamatkan } \\
\text { oleh Pangeran, } \\
\text { Putri mengikuti } \\
\text { Pangeran }\end{array}$ & $\begin{array}{l}\text { Berhasil } \\
{[\sqrt{ }]} \\
\text { Tidak } \\
\text { Berhasil } \\
{[\text { ] }}\end{array}$ & \\
\hline \multirow[t]{5}{*}{2} & $\begin{array}{l}\text { Menj } \\
\text { awab } \\
\text { Perta } \\
\text { nyaan }\end{array}$ & $\begin{array}{l}\text { Perta } \\
\text { nyaan } \\
\text { ke }-1\end{array}$ & $\begin{array}{l}\text { Ketika masuk } \\
\text { pertanyaan ke-1 } \\
\text { maka akan } \\
\text { diberikan } \\
\text { pertanyaan } \\
\text { tentang mulut }\end{array}$ & $\begin{array}{l}\text { Berhasil } \\
{[\sqrt{ }]} \\
\text { Tidak } \\
\text { Berhasil } \\
{[\text { ] }} \\
\end{array}$ & \\
\hline & & $\begin{array}{l}\text { Perta } \\
\text { nyaan } \\
\text { ke }-2\end{array}$ & $\begin{array}{l}\text { Ketika masuk } \\
\text { pertanyaan ke- } 2 \\
\text { maka akan } \\
\text { diberikan } \\
\text { pertanyan } \\
\text { tentang Enzim }\end{array}$ & $\begin{array}{l}\text { Berhasil } \\
{[\sqrt{ }]} \\
\text { Tidak } \\
\text { Berhasil } \\
\text { [ ] }\end{array}$ & \\
\hline & & $\begin{array}{l}\text { Perta } \\
\text { nyaan } \\
\text { ke- } 3\end{array}$ & $\begin{array}{l}\text { Ketika masuk } \\
\text { pertanyaan ke- } 3 \\
\text { maka akan } \\
\text { diberikan } \\
\text { pertanyaan } \\
\text { tentang gigi }\end{array}$ & $\begin{array}{l}\text { Berhasil } \\
{[\sqrt{ }]} \\
\text { Tidak } \\
\text { Berhasil } \\
\text { [ ] }\end{array}$ & \\
\hline & & $\begin{array}{l}\text { Perta } \\
\text { nyaan } \\
\text { ke- } 4\end{array}$ & $\begin{array}{l}\text { Ketika masuk } \\
\text { pertanyaan Ke- } \\
4 \text { maka muncul } \\
\text { pertanyaan } \\
\text { fungsi gigi }\end{array}$ & $\begin{array}{l}\text { Berhasil } \\
{[\sqrt{ }]} \\
\text { Tidak } \\
\text { Berhasil } \\
\text { [ ] }\end{array}$ & \\
\hline & & $\begin{array}{l}\text { Perta } \\
\text { nyaan } \\
\text { ke- } 5\end{array}$ & $\begin{array}{l}\text { Ketika masuk } \\
\text { pertanyaan ke- } \\
5 \text { maka akan } \\
\text { diberikan } \\
\text { pertanyaan } \\
\text { tentang Usus }\end{array}$ & $\begin{array}{l}\text { Berhasil } \\
{[\sqrt{ }]} \\
\text { Tidak } \\
\text { Berhasil } \\
\text { [ ] }\end{array}$ & \\
\hline
\end{tabular}




\begin{tabular}{|c|c|c|c|c|}
\hline $\begin{array}{l}\mathrm{N} \\
\mathrm{O}\end{array}$ & $\begin{array}{l}\text { Kasus } \\
\text { / } \\
\text { Diuji }\end{array}$ & $\begin{array}{l}\text { Skena } \\
\text { rio } \\
\text { Uji }\end{array}$ & $\begin{array}{l}\text { Hasil yang } \\
\text { diharapkan }\end{array}$ & $\begin{array}{l}\text { Hasil } \\
\text { Pengujian }\end{array}$ \\
\hline \multirow[t]{2}{*}{3} & \multirow[t]{2}{*}{$\begin{array}{l}\text { Jawa } \\
\text { ban }\end{array}$} & $\begin{array}{l}\text { Jawa } \\
\text { ban } \\
\text { Benar }\end{array}$ & $\begin{array}{l}\text { Ketika memilih } \\
\text { jawaban benar, } \\
\text { akan tampil teks } \\
\text { Bagus, silahkan } \\
\text { lewat }\end{array}$ & $\begin{array}{l}\text { Berhasil } \\
{[\sqrt{ }]} \\
\text { Tidak } \\
\text { Berhasil } \\
{[\text { ] }}\end{array}$ \\
\hline & & $\begin{array}{l}\text { Jawa } \\
\text { ban } \\
\text { Salah }\end{array}$ & $\begin{array}{l}\text { Ketika memilih } \\
\text { jawaban tetapi } \\
\text { salah maka akan } \\
\text { tampil teks } \\
\text { salah, coba lagi }\end{array}$ & $\begin{array}{l}\text { Berhasil } \\
{[\sqrt{ }]} \\
\text { Tidak } \\
\text { Berhasil } \\
{[]}\end{array}$ \\
\hline \multirow[t]{2}{*}{4} & \multirow[t]{2}{*}{ Мар } & $\begin{array}{l}\text { Mele } \\
\text { wati } \\
\text { map } \\
\text { denga } \\
\mathrm{n} \\
\text { benar }\end{array}$ & $\begin{array}{l}\text { Ketika map } \\
\text { dilewati oleh } \\
\text { karakter maka } \\
\text { map tersebut } \\
\text { tidak akan bisa } \\
\text { dilewati oleh } \\
\text { karakter }\end{array}$ & $\begin{array}{l}\text { Berhasil } \\
\text { [ ] } \\
\text { Tidak } \\
\text { Berhasil } \\
\text { [ ] }\end{array}$ \\
\hline & & $\begin{array}{l}\text { Mele } \\
\text { wati } \\
\text { map } \\
\text { denga } \\
\mathrm{n} \\
\text { salah }\end{array}$ & $\begin{array}{l}\text { Ketika map } \\
\text { dilewati oleh } \\
\text { karakter maka } \\
\text { map tersebut } \\
\text { akan bisa } \\
\text { dilewati oleh } \\
\text { karakter }\end{array}$ & $\begin{array}{l}\text { Berhasil } \\
\text { [ ] } \\
\text { Tidak } \\
\text { Berhasil } \\
\text { [ ] }\end{array}$ \\
\hline \multirow{4}{*}{5} & \multirow{4}{*}{$\begin{array}{l}\text { Karak } \\
\text { ter } \\
\text { Berge } \\
\text { rak }\end{array}$} & $\begin{array}{l}\text { Berge } \\
\text { rak } \\
\text { Keata } \\
\text { s }\end{array}$ & $\begin{array}{l}\text { Ketika menekan } \\
\text { tombol button } \\
\text { UP maka } \\
\text { karakter akan } \\
\text { bergerak ke atas }\end{array}$ & $\begin{array}{l}\text { Berhasil } \\
{[\sqrt{ }]} \\
\text { Tidak } \\
\text { Berhasil } \\
{[]}\end{array}$ \\
\hline & & $\begin{array}{l}\text { Berge } \\
\text { rak } \\
\text { Ke } \\
\text { Bawa } \\
\text { h }\end{array}$ & $\begin{array}{l}\text { Ketika menekan } \\
\text { tombol button } \\
\text { Down maka } \\
\text { karakter akan } \\
\text { bergerak ke } \\
\text { bawah }\end{array}$ & $\begin{array}{l}\text { Berhasil } \\
{[\sqrt{ }]} \\
\text { Tidak } \\
\text { Berhasil } \\
{[]}\end{array}$ \\
\hline & & $\begin{array}{l}\text { Berge } \\
\text { rak } \\
\text { Ke } \\
\text { Kana } \\
\mathrm{n}\end{array}$ & $\begin{array}{l}\text { Ketika tombol } \\
\text { button Right } \\
\text { ditekan, karakter } \\
\text { akan bergerak } \\
\text { ke kanan }\end{array}$ & $\begin{array}{l}\text { Berhasil } \\
{[\sqrt{ }]} \\
\text { Tidak } \\
\text { Berhasil } \\
{[]}\end{array}$ \\
\hline & & $\begin{array}{l}\text { Berge } \\
\text { rak } \\
\text { Ke } \\
\text { Kiri }\end{array}$ & $\begin{array}{l}\text { Ketika menekan } \\
\text { tombol button } \\
\text { Left maka } \\
\text { karakter akan } \\
\text { bergerak ke kiri }\end{array}$ & $\begin{array}{l}\text { Berhasil } \\
{[\sqrt{ }]} \\
\text { Tidak } \\
\text { Berhasil } \\
{[]}\end{array}$ \\
\hline
\end{tabular}

Berdasarkan hasil pengujian diatas maka penyusun menarik kesimpulan bahwa aplikasi multimedia pembelejaran materi organ pencernaan ini secara fungsional mengeluarkan hasil sesuai dengan yang diharapkan.

Game bergenre RPG ini mengajarkan bahwa pencernaan manusia terdiri dari beberapa step atau bagian. Game ini yang membahas organ-organ pencernaan manusia, seperti halnya gigi, enzim dan fungsifungsi gigi dan enzim. Diharapkan Game ini bisa menjadi media belajar siswa yang bersifat interaktif dan atraktif khususnya siswa-siswi kelas V Sekolah Dasar. 


\section{KESIMPULAN DAN SARAN}

\subsection{Kesimpulan}

Berdasarkan uraian dan hasil analisa yang telah dilaksanakan, maka dapat ditarik kesimpulan sebagai berikut :

1. Rancangan aplikasi dari Game ini bisa digunakan sebagai media pembelajaran untuk materi fungsi pencernaan manusia yang ada dalam mata pelajaran IPA untuk anak kelas V SD.

2. Aplikasi multimedia game edukasi ini bisa dijadikan sebagai media alternatif bagi anak kelas V SD untuk belajar mata pelajaran IPA materi organ pencernaan yang dijalankan menggunakan komputer.

3. Game edukasi ini dapat meningkatkan dan mempermudah siswa dalam menerima pelajaran untuk materi organ pencernaan.

\subsection{Saran}

Sebagai saran yang dapat diberikan dalam pembuatan Aplikasi multimedia game edukasi Ilmu Pengetahuan Alam ini yaitu :

1. Penyusun berharap Game yang dibuat dapat dikembangkan lagi, dimana mengacu pada materi ajar lainnya.

2. Game ini dapat dikembangkan lebih beragam lagi dalam hal animasi, desain, fitur, musik serta pemograman yang lebih efektif.

3. Metode pembelajaran berbasis Game ini mustinya, bisa dijadikan alat bantu atau sebagai alat pemacu dalam proses kegiatan belajar mengajar.

4. Penulis berharap agar metode pembelajaran berbasis Game bisa diterapkan di setiap sekolah.

\section{DAFTAR PUSTAKA}

[1] Abdul, Halim Fathani. (2009). Matematika Hakikat dan Logika. Yogyakarta : Ar-Ruzz

[2] Sutarman. 2009. Pengantar Teknologi Informasi. Jakarta: PT Bumi Aksara.

[3] Briggs, Leslie J. 1997. Instructional Design, Educational Technology Publications Publication Inc. New Jersey : Englewood Cliffs.

[4] Sagala, Syaiful. 2007. Manajemen Strategik dalam Peningkatan Mutu Pendidikan. Bandung: Alfabeta.

[5] Wihardjo, Edy. 2007. Pembelajaran Berbantuan Komputer. www.elearning.baktiinangpersada.ac.id. Akses terakhir 02 Juli 2020.

[6] Idris, H. 2008. Pengembangan multimedia pembelajaran Berbantuan computer. Januari. 51-52

[7] Arsyad, Azhar. 2003. Media Pembelajaran, Jakarta: Raja Grafindo Persada.

[8] Lakoro, Rahmatsyam \& Mohamad Hariadi .2008. Pengembangan Ikon pada Graphical User Interface untuk Game Edukasi dengan Icon Intuitiveness Test. Bandung: Sesindo ITS 2008

[9] Jasson. 2009. Role Playing Game (RPG) Maker. Yogyakarta: CV. Andi Offset.

[10] Radion, Kristo. 2009. Ultimate Game Design. Yogyakarta: CV. Andi Offset. 